\title{
Influence of Foaming Agent/Water Ratio and Foam/Geopolymer Paste Ratio to the Properties of Fly Ash-based Lightweight Geopolymer for Brick Application
}

\author{
WAN MASTURA WAN IBRAHIM ${ }^{1 *}$, KAMARUDIN HUSSIN ${ }^{1,2}$, MOHD MUSTAFA AL BAKRI ABDULLAH ${ }^{1,2}$, \\ AESLINA ABDUL KADIR ${ }^{3}$, LAILA MARDIAH DERAMAN ${ }^{1}$, ANDREI VICTOR SANDU ${ }^{1,4,5 *}$ \\ ${ }^{1}$ Center of Excellence Geopolymer and Green Technology, School of Material Engineering, Universiti Malaysia Perlis \\ (UniMAP), Kangar, Perlis, Malaysia \\ 2 Faculty of Engineering Technology, Universiti Malaysia Perlis (UniMAP), Perlis, Malaysia \\ ${ }^{3}$ Faculty of Civil and Environmental Engineering, Universiti Tun Hussein Onn Malaysia (UTHM), Johor, Malaysia. \\ ${ }^{4}$ Gheorghe Asachi Technical University of lasi, Faculty of Materials Science and Engineering, 41 D. Mangeron Blvd., 700050, Iasi, \\ Romania \\ ${ }^{5}$ Romanian Inventors Forum, Str. Sf. P. Movila 3, 700089, Iasi, Romania
}

\begin{abstract}
Nowadays, the demand for lightweight building materials has been growing worldwide. This paper presents an investigation on the use of waste materials of fly ash as a source materials for the production of lightweight geopolymer by using foaming agents. The key properties for the foamed geopolymer namely density, compressive strength, and water absorption were investigated. The chemical composition of materials and morphology analysis were studied to find the microstructure properties of foamed geopolymer. The foamed geopolymer were prepared by combination of $12 \mathrm{M}$ Sodium Hydroxide $(\mathrm{NaOH})$ solution and Sodium Silicate ( $\mathrm{Na}_{2} \mathrm{SiO}_{3}$ ) solution. The ratio of $\mathrm{Na} \mathrm{SiO}_{\mathrm{f}} \mathrm{NaOH}$ and ratio of fly ash/alkaline activator were kept constant at 2.5 and 2.0, by mass respectively. The effect of different ratio of foaming agent/water and foam/geopolymer paste were investigated at 7 days of ageing and cured at $80^{\circ} \mathrm{C}$ for 24 hours. In general, the results showed that the fly ash-based lightweight geopolymer has good potential as brick application.
\end{abstract}

Keywords: lightweight brick, geopolymer, foaming agent/water ratio, foam/geopolymer paste ratio

Brick is one of the most important building material in construction industry. Manufacturing of conventional brick are generally uses of clay with high temperature kiln firing or from ordinary Portland cement (OPC) concrete [1]. The high temperature kiln firing $\left(900-1000^{\circ} \mathrm{C}\right)$ not only consumes significant amount of energy, but also releases substantial quantity of greenhouse gases [2]. Production of OPC concrete bricks also consumes large amount of energy and releases substantial quantity of $\mathrm{CO}_{2}$. This is because the production of $1 \mathrm{~kg}$ of OPC consumes approximately $1.5 \mathrm{kWh}$ of energy and releases about $1 \mathrm{~kg}$

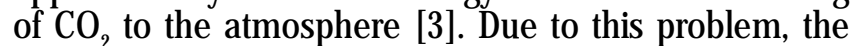
utilization of waste materials has been studied by several researchers focused on the environmental protection and sustainable development [4-6]. The uses of fly ash, which is a waste produced from the thermal power plant can be used as a cement and clay replacement in making bricks through geopolymerization process.

Geopolymerization occurs through the reaction between aluminosilicate source materials with highly alkaline solutions. The alkaline activator solution are usually come from the combination of sodium hydroxide and sodium silicate or a potassium hydroxide and potassium silicate solution [7]. Most waste materials such as fly ash, blast furnace slag and mine tailings contain sufficient amounts of reactive alumina and silica can be used as source materials for geopolymerisation reactions [8]. Among the above mentioned waste materials, fly ash get most consideration to be a source materials in manufacturing of geopolymer due to their genially structure and size, also they contains high levels of amorphous silica and alumina [9]. Geopolymers are fire-resistant materials and hence, fabricating lightweight geopolymers [10-17] with enhanced thermal resistivity, reduced the density and improved other properties can be considered as an effective way of their usage in brick application [18]. Some attempts have been made to produce lightw eight geopolymer using different types of foaming agent such as aluminium (Al) powder [18-20], hydrogen peroxide $\left(\mathrm{H}_{2} \mathrm{O}_{2}\right)[9,21,22]$, and sodium hypochlorite $(\mathrm{NaOCl})[23$, 24].

In this paper, the fly ash-based lightweight geopolymer was prepared using class $\mathrm{F}$ fly ash, alkaline activator solution ( $\mathrm{NaOH}$ solution $+\mathrm{Na}_{2} \mathrm{SiO}_{3}$ solution) and synthetic foaming agent using geopolymerization process. The foaming agents was prepared through pre-forming method byusing foam generator before mixing with the geopolymer paste. Influences of foaming agent/water ratio and foam/ geopolymer paste ratio to the physical, mechanical and microstructure properties of lightweight geopolymer were investigated. The results will be very beneficial for the lightweight geopolymer bricks application and energy efficiency of building materials.

\section{Experimental part}

Materials and method

The characterization of the raw materials

Class F Fly ash was obtained from Cirebon (Indonesia) was used as source material and the chemical composition shown in table 1. The morphology structure of original class Table 1

CHEMICAL COMPOSITION OF FLY ASH

\begin{tabular}{|l|l|l|l|l|l|l|l|l|l|l|l|l|}
\hline $\begin{array}{l}\text { Chemical } \\
\text { composition }\end{array}$ & $\mathrm{SiO}_{2}$ & $\mathrm{Al}_{2} \mathrm{O}_{3}$ & $\mathrm{Fe}_{2} \mathrm{O}_{3}$ & $\mathrm{TiO}_{2}$ & $\mathrm{CaO}$ & $\mathrm{MgO}$ & $\mathrm{Na}_{2} \mathrm{O}$ & $\mathrm{K}_{2} \mathrm{O}$ & $\mathrm{P}_{2} \mathrm{O}_{5}$ & $\mathrm{SO}_{3}$ & $\mathrm{MnO}$ & $\mathrm{LOI}$ \\
\hline Percentage (\%) & 47.28 & 16.59 & 20.30 & 0.86 & 6.98 & 4.20 & 0.46 & 0.84 & 0.11 & 1.60 & 0.29 & 1.57 \\
\hline
\end{tabular}

\footnotetext{
* email: wanmastura@unimap.edu.my or sav@tuiasi.ro
} 
Table 2

CHEMICAL COMPOSITION OF FOAMING AGENT (POLYOXYETHYLENE ALKYETHER SULFATE)

\begin{tabular}{|l|c|c|c|c|c|c|c|c|}
\hline Chemical composition & $\mathrm{SiO}_{2}$ & $\mathrm{SO}_{3}$ & $\mathrm{~K}_{2} \mathrm{O}$ & $\mathrm{CaO}$ & $\mathrm{Sc}_{2} \mathrm{O}_{3}$ & $\mathrm{CuO}$ & $\mathrm{PdO}$ & $\mathrm{OsO}_{2}$ \\
\hline Percentage (\%) & 1.80 & 78.60 & 1.60 & 4.20 & 0.10 & 2.20 & 11.0 & 0.90 \\
\hline
\end{tabular}

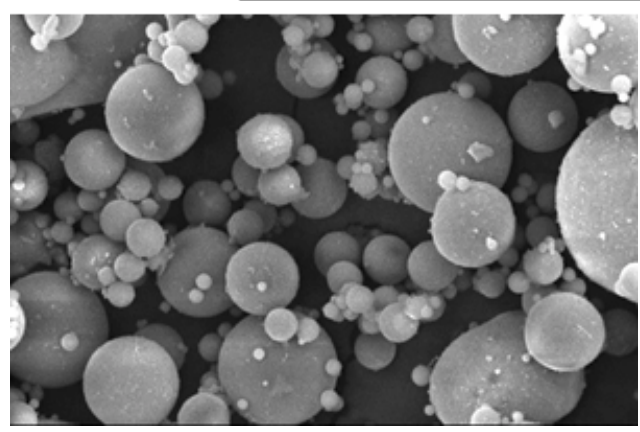

Fig. 1.

Microstructure of fly ash

F fly ash was depicted in figure 1 . Surfactants or synthetic foaming agent (Polyoxyethylene Alkyether Sulfate) was used as the foaming agents and the chemical composition shown in table 2. Analytical grade Sodium Hydroxide $(\mathrm{NaOH})$ and sodium silicate $\left(\mathrm{Na}_{2} \mathrm{SiO}_{3}\right)$ solution with $\mathrm{SiO}: \mathrm{Na}_{2} \mathrm{O}$ weight ratio of 3.20 were used as alkaline solutions. All experiments were performed using the same batches of alkaline solutions and starting materials. Distilled water was used to dissolve $\mathrm{NaOH}$ pallet in preparation of $12 \mathrm{M} \mathrm{NaOH}$ solution.

From table 1, the results shows that the major constituents of fly ash are $\mathrm{SiO}_{2}, \mathrm{Al}_{2} \mathrm{O}_{3}$, and $\mathrm{Fe}_{2} \mathrm{O}_{3}$, with $47.28 \%, 16.59 \%$ and $20.30 \%$, respectively. The total of $\mathrm{SiO}_{2}$ $+\mathrm{Al}_{2} \mathrm{O}_{3}+\mathrm{Fe}_{2} \mathrm{O}_{3}>70 \%$ indicated that this fly ash was classified as class F fly ash according to the ASTM C 618 Standard specifications [25]. The major constituents of foaming agent used in this study (table 2) are $\mathrm{SO}_{3}$ and $\mathrm{PdO}$ with $78.60 \%$ and $11.0 \%$, respectively. This type of foaming agent are called as synthetic foaming agent which are an amphiprotic substance that are strongly hydrophilic and easily dissolve in water yielding air bubbles [26].

Figure 1 represents the microstructure of class $\mathrm{F}$ fly ash characterized by Scanning Electron Microscope (SEM). The structure of original fly ash shows that the shape was nearly spherical particles with various sizes. These particles are usually consists of fine solid spherical particles (microspheres) which are contained by the large cenosphere particles $(>50 \mu \mathrm{m})$ formed during the combustion process [27]. The surface texture of fly ash are mostly smooth and also some vitreous, unshaped fragments or quartz particles can be seen [28].

\section{Mix design}

In this research, the ratios of foaming agent/water used are $1 / 10,1 / 20,1 / 30$ and $1 / 40$, by volume and the ratio of foam/geopolymer paste used are $0.5,1.0,1.5$ and 2.0 , by volume. The optimum concentration of $\mathrm{NaOH}$ solution (12 M) found from the effects of $\mathrm{NaOH}$ molarity was fixed for all the mixtures and the ratio of $\mathrm{Na}_{2} \mathrm{SiO}_{3} / \mathrm{NaOH}$ solution and fly ash/alkaline activator solution was fixed at 2.5 and 2.0, by mass respectively. The details of the mix design for the various ratios of foaming agent/water and foam/ geopolymer paste are shown in table 3.

\section{Preparation of the fly ash-based lightweight geopolymer}

The lightweight geopolymer were produced using prefoamed method where the foam was prepared first before adding to the geopolymer paste. The geopolymer paste were manufactured by mixing fly ash and alkaline activator solution at a given fly ash/alkaline activator mass ratio in a laboratory mixer.

In the laboratory mixer, the $\mathrm{NaOH}$ solution and $\mathrm{Na}_{3} \mathrm{SiO}_{3}$ solution were mixed first for 5 min to prepare alkâline activator solution. Then the fly ash was added to the alkaline activator solution and continues mixing for another 5 minutes until the mixture homogeneous to get the geopolymer paste. Certain amount of foaming agent is added to the geopolymer pastes according to the given ratio to produce lightweight geopolymer paste. The lightweight geopolymer pastes were then poured into 50 $\times 50 \times 50 \mathrm{~mm}$ cubic moulds. Samples are sealed and cured in the oven at $80^{\circ} \mathrm{C}$ for $24 \mathrm{~h}$. After $24 \mathrm{~h}$ of curing process, the samples were demoulded and left at room temperature $\left(20-24^{\circ} \mathrm{C}\right)$ for 7 days of ageing before tested. Minimum of three samples were prepared for each mix design.

Table 3

MIX DESIGN FOR VARIOUS RATIOS OF FOAMING AGENT/WATER AND GEOPOLYMER PASTE/FOAM

\begin{tabular}{|c|c|c|c|c|c|c|}
\hline Mix no. & $\begin{array}{c}\text { Ratio of } \\
\text { foaming } \\
\text { agent/water }\end{array}$ & $\begin{array}{c}\text { Ratio of } \\
\text { foam/geopolymer } \\
\text { paste }\end{array}$ & $\begin{array}{l}\text { Mass of fly } \\
\text { ash used } \\
\text { (g) }\end{array}$ & $\begin{array}{l}\text { Mass of } \\
\mathrm{NaOH} \\
\text { used (g) }\end{array}$ & $\begin{array}{l}\text { Mass of } \\
\mathrm{Na}_{2} \mathrm{SiO}_{3} \\
\text { used (g) }\end{array}$ & $\begin{array}{c}\begin{array}{c}\text { Volume of } \\
\text { foam used } \\
(\mathrm{ml})\end{array} \\
\end{array}$ \\
\hline 1 & \multirow{4}{*}{$1 / 10$} & 0.5 & \multirow{4}{*}{468.7} & \multirow{4}{*}{67.0} & \multirow{4}{*}{167.4} & 250 \\
\hline 2 & & 1.0 & & & & 500 \\
\hline 3 & & 1.5 & & & & 750 \\
\hline 4 & & 2.0 & & & & 1000 \\
\hline 5 & \multirow{4}{*}{$1 / 20$} & 0.5 & \multirow{4}{*}{468.7} & \multirow{4}{*}{67.0} & \multirow{4}{*}{167.4} & 250 \\
\hline 6 & & 1.0 & & & & 500 \\
\hline 7 & & 1.5 & & & & 750 \\
\hline 8 & & 2.0 & & & & 1000 \\
\hline 9 & \multirow{4}{*}{$1 / 30$} & 0.5 & \multirow{4}{*}{468.7} & \multirow{4}{*}{67.0} & \multirow{4}{*}{167.4} & 250 \\
\hline 10 & & 1.0 & & & & 500 \\
\hline 11 & & 1.5 & & & & 750 \\
\hline 12 & & 2.0 & & & & 1000 \\
\hline 13 & \multirow{4}{*}{$1 / 40$} & 0.5 & \multirow{4}{*}{468.7} & \multirow{4}{*}{67.0} & \multirow{4}{*}{167.4} & 250 \\
\hline 14 & & 1.0 & & & & 500 \\
\hline 15 & & 1.5 & & & & 750 \\
\hline 16 & & 2.0 & & & & 1000 \\
\hline
\end{tabular}


Physical, mechanical and microstructure tests

The compressive strength test for lightweight geopolymer was carried out according to ASTM C109 by using Universal Testing Machine (UTM), Shimadzu Japan, $\mathrm{UH}-1000 \mathrm{kNI}$ at the rate of load speed $0.6 \mathrm{~N} / \mathrm{mm}^{2} / \mathrm{s}$. The lightweight geopolymer samples were tested at 7 days and three samples are tested to evaluate the average strength. The strength was recorded in $\mathrm{N} / \mathrm{mm}^{2}$ to the nearest $0.1 \mathrm{~N} / \mathrm{mm}^{2}$. The compressive strength of lightweight geopolymer is calculated based on the equation 1.

$$
\sigma_{\mathrm{c}}=\frac{F}{A}
$$

where,

$\sigma_{\mathrm{c}}=$ Compressive strength

$\mathrm{F}^{\mathrm{c}}=$ Applied load $(\mathrm{N})$

$A=$ Area of the face subjected to loading $\left(\mathrm{mm}^{2}\right)$

The density of lightweight geopolymer can be calculated by the formula as shown in equation 2 below. Cubic samples $(50 \times 50 \times 50 \mathrm{~mm})$ were used for the density measurements. The reported density results were come from the average of three samples measurement.

$$
\text { Density, } \rho=\frac{\text { Mass }, M}{\text { Volume, } V}
$$

The water absorption test has been conducted according to the ASTM C140-12 standard to record the water absorbed by lightweight geopolymer. Three samples have been tested for each different parameter for their absorption test. Water absorption was determined by the equation 3 below.

$$
\text { Water absorption }=\frac{W s-W d}{W d} \times 100
$$

Ws $=$ saturated weight of samples $(g)$

$\mathrm{Wd}=$ oven-dry weight of samples $(\mathrm{g})$

The microstructure of fly ash and lightweight geopolymer samples were analysed using JEOL J SM6460LA model Scanning Electron Microscope (SEM) from Japan. Samples were coated with palladium by using Auto Fine Coater JEOL JFC 1600 model and analysed under high vacuum conditions with an accelerating voltage of $20 \mathrm{kV}$.

\section{Results and discussions}

\section{Compressive strength}

The results of compressive strength of fly ash-based lightweightgeopolymer with various ratio of foaming agent/ water (by volume) and foam/geopolymer paste (by volume) are shown in figure 2. The strength of lightweight geopolymer is directly affected by the foaming agent content. The increase in ratio of foaming agent/water (by volume) and ratio of foam/geopolymer paste (by volume) decreased the compressive strength of lightweight geopolymer. The lowest strength ( $4.1 \mathrm{MPa}$ ) was observed at ratio of foaming agent/water (by volume) of $1 / 40$ with ratio of foam/geopolymer paste 2.0, by volume. The highest strength (17.8 MPa) achieved at ratio foam/geopolymer paste 0.5 and ratio of foaming agent/water of $1 / 10$, by volume. The strength obtained from this study was similar to the research done by Risdanareni et al., [ 29] which also found that the strength decreased with increasing the doses of foaming agent from 0 to $0.9 \%$. The compressive strength of lightw eight geopolymer is closely related to its density, both decreasing with the addition of foaming agent

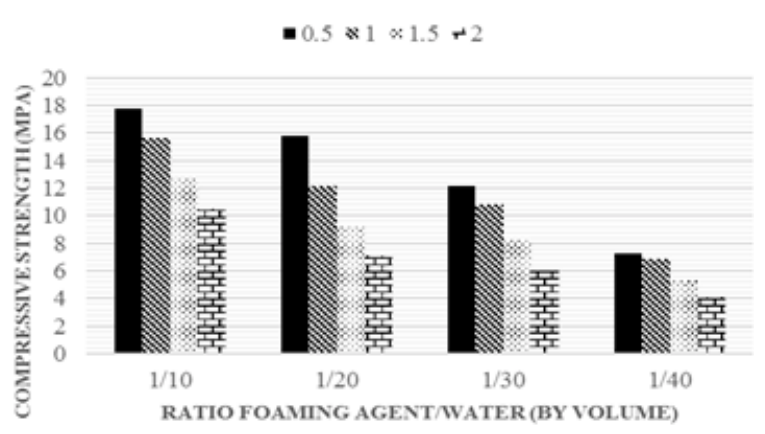

Fig. 2. Compressive strength of lightweight geopolymer with different ratio of foaming agent/water and ratio of foam/paste

[30]. At a higher foam volume, the merging of bubbles seemed to produce larger voids that result in a wide distribution of void size and lower strength [31].

\section{Water absorption}

]The water absorption of fly ash-based lightweight geopolymer were presented in figure 3. The lowest water absorption (4.8\%) was depicted at foaming agent/water ratio of $1 / 10$ and foam/geopolymer paste ratio of 0.5 , by volume. The highest water absorption (21.6\%) was found in a sample with a foaming agent/water ratio of $1 / 40$ and foam/geopolymer paste ratio of 2.0 , by volume. These results shows that the increasing of foaming agent content caused increases amount of pore which contributed to the increasing in water absorption value. Masi et al. [32] have also showed an increasing trend of water absorption values, with increasing the amount of foaming agent in geopolymer paste. It was influenced by the extent of large pores which are not completely filled by water due to air present in the cavities [32]. Furthermore, with the increasing volumes of foam, more and more interconnected pores which are benefit for flow of water are appeared causes the increase of water absorption [33] .

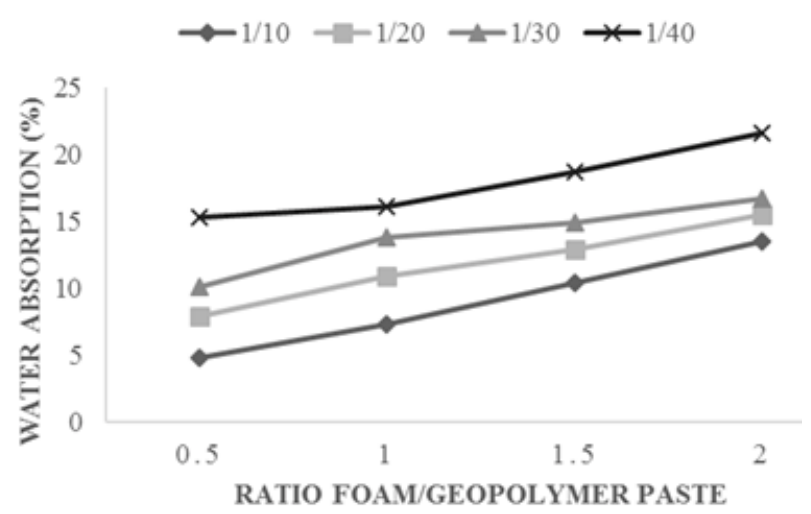

Fig. 3. Water absorption of lightweight geopolymer with different ratio of foaming agent/water and ratio of foam/paste

\section{Density}

Figure 4 showed the density values of lightweight geopolymer with various ratio of foaming agent/water and foam/geopolymer paste. The density data shown in figure 4 is average value of three samples and the results reported the density values are in the range between $900 \mathrm{~kg} / \mathrm{m}^{3}$ to $1650 \mathrm{~kg} / \mathrm{m}^{3}$. As can be seen from figure 4, the highest (1650 $\mathrm{kg} / \mathrm{m}^{3}$ ) density value was presented at the samples with the ratio of foaming agent/water of $1 / 10$, by volume and ratio of foam/geopolymer paste of 0.5 , by volume, respectively. While, the lowest $\left(920 \mathrm{~kg} / \mathrm{m}^{3}\right)$ density value appeared at the sample with the ratio of foaming agent/ water of $1 / 40$, by volume and ratio of foam/geopolymer 


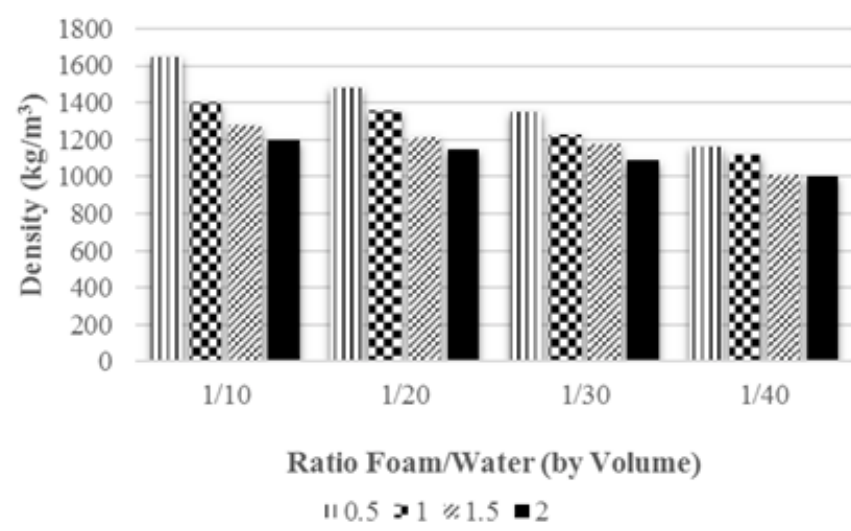

Fig. 4. The density values of lightweight geopolymer with different ratio of foaming agent/water and ratio of foam/paste

paste of 2.0, by volume, respectively. It was clearly shows that an increase in the volume of foaming agent decreased the density of lightweight geopolymer. The increase of foaming agent caused the amount of voids inside the material with air contained could be generated, thus resulting in the reduction of density [9]. Liu et al. [31] reported that the addition of foam reduced the density due to the creation of tiny air bubbles in the geopolymer samples, which resulted in higher porosity and reduced compressive strength of foamed geopolymer.

\section{Microstructure properties}

Figure 5 shows the morphology structure of the lightweight geopolymer with different ratio of foam/ geopolymer paste. The unreacted fly ash particles are still appeared for all the samples of lightweight geopolymer with different ratio of foam/geopolymer paste; (a) 0.5 , (b) 1.0, (c) 1.5 and (d) 2.0, by volume. A few small and large pores can be seen in all lightweight geopolymer samples. Figure 5 reports the quantity and size of the pores appeared from the samples investigated in this study, showing that, for a ratio of foam/geopolymer paste of 2.0, by volume, the pore size become larger and the quantity of pores generated seems to be an increasing as compared to the samples with the ratio of foam/geopolymer paste of 0.5 , by volume. The results shows that the greater the volume obtained in the foam is, the greater the average pore size becomes [34]. These results confirm that the difference amount of foaming agent added to the geopolymer paste can influence the microstructure of lightweight geopolymer. According to Liu etal. [35], the relative smaller pores in the matrix decrease and relative larger pores in the matrix increase with increasing foaming agent $\left(\mathrm{H}_{2} \mathrm{O}_{2}\right)$ content. However, when the content of the foam-stabilizer (1.0wt\% sodium dodecyl benzene sulfonate and $0.8 w t \%$ triethanolamine) increases, the macro-pores distribute in the matrix become more consistently by interface modification.

\section{Conclusions}

In present works, the lightweight geopolymer were successfully produced by using waste materials and low energy through geopolymerization process. The novel synthetic foaming agent, polyoxyethylene alkyether sulfate, used in this study provided good foaming of the geopolymers for producing lightweight geopolymer. The compressive strength of lightweight geopolymer reduces with decreasing the density of specimens. By increasing the amount of foaming agent used, the density of specimens decreased, hence produce low strength and
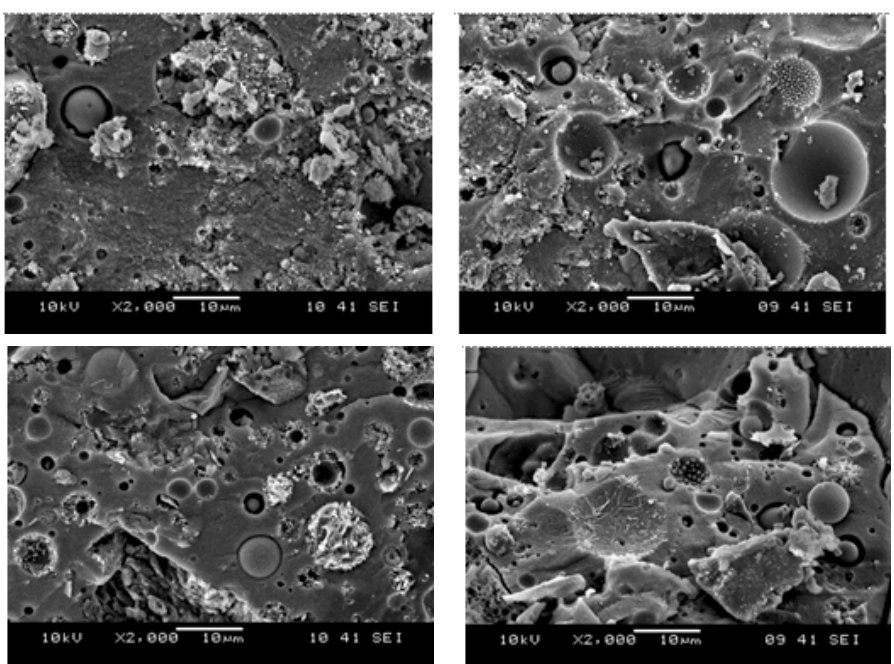

Fig. 5. Microstructure of fly ash-based lightweight geopolymer with ratio of foaming agent/water $1 / 10$, (a) 0.5 , (b) 1.0 , (c) 1.5 and (d) 2.0 of ratio foam/geopolymer paste, by volume

high water absorption. The optimum foaming agent/water ratio was selected at $1 / 10$, by volume and foam/ geopolymer paste $=1.0$, by volume which had a strength of $15.6 \mathrm{MPa}$, water absorption of $7.3 \%$ and density of 1400 $\mathrm{kg} / \mathrm{m}^{3}$ according to the requirement for lightweight concrete bricks as stated in ASTM Standard C55 [28]. From the findings in this study, it was concluded that the lightweight geopolymer prepared from this study can be used for lightweight bricks application.

Acknowledgements: This study was supported by Center of Excellence Geopolymer and Green Technology (CEGeoGTECH) UniMAP and School of Materials Engineering, UniMAP.

\section{References}

1.ZHANG L., Constr. Build. Mater., 47, 2013, p. 643

2.AHMARI S., L. ZHANG, Constr. Build. Mater., 29, 2012, p. 323

3.Murekar P. N. R., Intern. Conf. Rec. Tren Eng. Sci. Techno. (ICRTEST 2017), 5, no. 1, 2017, p. 467

4.KADIR A. A., MOHAJERANI D. A., in International Conference Environmental Managementand Engineering (EME 2011), 2011, p. 108 5.ARSHAD, M. S., PAWADE P. Y., Intern. J. Sci. Techno. Res, 3, no. 6, 2014, p. 49

6.J OSE MATHEW B., NATARAJ AN C., Eur. Int. J. Sci. Technol., 2, no. 5, 2013, p. 133

7.DAVIDOVITS J., 99 Geopolymer International Conference Proceedings, (Editor R. D. and C. J. Joseph Davidovits), Saint-Quentin, France, 1999, p. 9

8.VAN JAARSVELD J. G.,. VAN DEVENTER J. S., LUKEY G., Chem. Eng. J., 89, no. 1-3, 2002, p. 63

9.FENG J., ZHANG R., GONG L., LI Y., CAO W., CHENG X., Mater. Des., 65, 2015, p. 529

10.AHMAD, R., ABDULLAH, M.M.A.B., HUSSIN, K., SANDU, A.V., BINHUSSAIN, M., JAYA, N.A., Reviews on Advanced Materials Science, 44, no. 1, 2016, p. 26.

11.RAMASAMY, S., HUSSIN, K., ABDULLAH, M.M.A.B., GHAZALI, C.M.R., SANDU, A.V.; BINHUSSAIN, M., SHAHEDAN, N.F., Reviews on Advanced Materials Science, 42, no. 1, 2015, p. 83.

12.ABDULLAH, M.M.A., TAHIR, M.F.M., HUSSIN, K., BINHUSSAIN, M., SANDU, I.G., YAHYA, Z., SANDU, A.V., Rev. Chim. (Bucharest), 66, no. 7, 2015, p. 1001.

13.ABDULLAH, M.M.A., NORDIN, N., TAHIR, M.F.M., KADIR, A.A., SANDU, A.V., International Journal Of Conservation Science, 7, no. 3, 2016, p. 753.

14.SHAHEDAN, N.F., ABDULLAH, M.M.A., HUSSIN, K., SANDU, I., GHAZALI, C.M.R., BINHUSSAIN, M., YAHYA, Z., SANDU, A.V., Mat. Plast., 51, no. 3, 2014, p. 258. 
15.FARIS, M.A., ABDULLAH, M.M.A., SANDU, A.V., ISMAIL, K.N., MOGA, L.M., NECULAI, O., MUNIANDY, R., Mat. Plast., 54, no. 1, 2017, p. 145. 16.J AFFAR, M.I., BADARUZZAMAN, W.H.W., ABDULLAH, M.M.A., BAHAROM, S., MOGA, L.M., SANDU, A.V., Mat. Plast., 52, no. 2, 2015, p. 243.

17.J . G. SANJ AYAN, A. NAZARI, L. CHEN, AND G. H. NGUYEN, Constr. Build. Mater., 79, 2015, p. 236

18.KEAW PAPASSON P., TIPPAYASAM C., RUANGJAN S., THAVORNITI P., PANYATHANMAPORN T., FONTAINE A., CHAYSUWAN D., Key Eng. Mater., 608, 2014, p. 132

19.DUCMAN V., KORAT L., Mater. Charact., 113, 2016, p. 207 20.TSAOUSI G.-M., DOUNI I., TAXIARCHOU M., PANIASD., PASPALIARIS I., IOP Conf. Ser. Mater. Sci. Eng., 123, no. 1, 2016

21.VAOU V., PANIAS D., Miner. Eng., 23, no. 14, 2010, p. 1146 22.BÖKE N., BIRCH G. D., NYALE S. M., PETRIK L. F., Constr. Build. Mater., 75, 2015, p. 189

23.NYALE S. M., BABAJ IDE O. O., BIRCH G. D., BÖKE N., PETRIK L. F., Procedia Environ. Sci., 18, 2013, p. 722

24.ASTM C 618-12. Standard Specification for Coal Fly Ash and Raw or Calcined Natural Pozzolan for Use, 2012.
25.PANESAR D. K., Constr. Build. Mater., 44, 2013, p. 575 26.ALEHYEN S., ACHOURI M. E. L., TAIBI M., J. Mater. Environ. Sci., 8, no. 5, 2017, p. 1783

27.ABDULLAH M. M. A. B., HUSSIN K., BNHUSSAIN M., ISMAIL K. N., YAHYA Z., RAZAK R. A., Int. J. Mol. Sci., 13, 2012, p. 7186

28.RISDANARENI P., HILMI A., SUSANTO P. B., AIP Conf. Proc., 1835, 2017, p. 1

29.ZHANG Z., PROVIS J. L., REID A., WANG H., Cem. Concr. Compos., 62, 2015, p. 97

30.LIU M. Y. J., ALENGARAM U. J., JUMAAT M. Z., MO K. H., Energy Build., 72, 2014, p. 238

31.MASI G., W. RICKARD D. A., VICKERS L., BIGNOZZI M. C., VAN RIESSEN A., Ceram. Int., 40, 2014, p. 13891

32.ZHAO Y., YE J., LU X., LIU M., LIN Y., GONG W., NING G., J. Hazard. Mater., 174, no. 1-3, 2010, p. 108

33.STROZI CILLA M., COLOMBO P., RAYMUNDO MORELLI M., Ceram. Int., 40, no. 4, 2014, p. 5723

34.LIU Z., SHAO N., WANG D., QIN J ., HUANG T., SONG W., WANG Z., Int. J. Miner. Metall. Mater., 21, no. 1, 2014, p. 89

35.ASTM C55-12. Standard Specification for Concrete Building Brick, 2012.

$\overline{\text { Manuscript received: } 14.03 .2017}$ 